\title{
PENERAPAN HUKUM PELAKU TINDAK PIDANA TURUT SERTA DALAM MENAWARKAN LAYANAN SEKSUAL (HUMAN TRAFFICKING) (Studi Putusan No 39/PID.SUS/2019/PN MET)
}

\author{
Oleh:
}

\author{
OktaAinita, Aprinisa, Agung Budi Wibowo \\ Program Studi Ilmu Hukum, Universitas Bandar Lampung \\ Email: okta.anita@ubl.ac.id, aprinisa@ubl.ac.id, agungpradana127@gmail.com
}

\begin{abstract}
Human Trafficking in Indonesia at this time is not only related to downstream issues within the scope of the policy on the implementation of trafficking in persons, such as the low response and commitment of the state, prevention and control measures are more reliant on the means of punishment, handling and enforcement much colored by dirty games and the lack of intensive and effective cooperation within the country and across national borders bilaterally, regionally and internationally. The problem that arises in the study is why do perpetrators of criminal acts participate in offering sexual services (Human Traficking) based on decision number 39 / PID.SUS / 2019 / PN Met? How does the application of law by judges against criminal offenses participate in offering sexual services based on decision number 39 / PID.SUS / 2019 / PN Met? How is the effort to tackle the crime of participating in offering sexual services based on decision number 39 / PID.SUS / 2019 / PN Met? Factors causing criminal acts are economic factors that are often more dominant lack of welfare and the difficulty of getting job vacancies makes people justify any means to get profit, someone to commit a crime that is prohibited and threatened with crime, habit factor is a characteristic of someone who like excessive life or luxury, then the shortcut he committed a crime and the opportunity factor is a factor that can also deliver someone to commit a crime. The application of the law by judges against criminal offenses participates in offering sexual services based on Decision Number 39 / PID.SUS / 2019 / PN Met. The Panel of Judges said that heeded the provisions of Article 30 Jo Article 4 Paragraph (2) of RI Law No.44 of 2008 concerning Pornography Jo Article 55 Paragraph (1) of the Criminal Code, Law Number 8 of 1981 concerning Criminal Procedure Law and Legislation other laws and regulations, the Metro City District Court Judge Board of Judges declared that the defendant has been legally proven and convincingly guilty of committing criminal offenses in participating in offering sexual services and convicting of Defendant I Hendi Bin M Lisin and Defendant II Lala Rizky Septiani Bint Muzirzain with imprisonment for 1 year each and a fine of Rp.250,000,000.00 (two hundred and fifty million rupiah). Recommendations, based on the factors that cause the perpetrators to commit criminal acts in offering sexual services, the Judges in this case in order to provide criminal sanctions against the perpetrators, the decision must be more severe because the actions of the defendant is a form of error that must be accounted for and does not exist justification or justification which eliminates criminal liability for the defendant. The judge should provide a fair criminal verdict for the
\end{abstract}


defendant meaning that it is intended to provide a deterrent impact on the perpetrators of the crime, so that it cannot repeat the same crime in the future. The government is expected to provide easy access to education for the community specifically for Metro City, providing verified employment, so as to reduce the growth of criminal offenses participating in offering sexual services.

\section{Keywords: Application of Law. Criminals, Participation, Sexual Services}

Perdagangan orang yang terjadi di Indonesia saat ini tidak hanya terkait persoalan-persoalan hilir dalam lingkup kebijakan implementasi perundang-undangan perdagangan orang, seperti masih rendahnya respond dan komitmen negara, tindakan pencegahan dan penanggulangan lebih mengandalkan sarana penal, penanganan dan penindakan banyak diwarnai dengan permainan kotor dan kurang intensif dan efektifnya kerjasama di dalam negeri maupun lintas batas negara secara bilateral, regional dan internasional.Permasalahan yang timbul dalam penelitian adalah Mengapa pelaku melakukan tindak pidana turut serta dalam menawarkan layanan seksual (Human Traficking) berdasarkan putusan nomor 39/PID.SUS/2019/PN Met? Bagaimana penerapan hukum oleh hakim terhadap pelaku tindak pidana turut serta dalam menawarkan layanan seksual berdasarkan putusan nomor 39/PID.SUS/2019/PNMet? Bagaimana upaya menanggulangi tindak pidana turut serta dalam menawarkan layanan seksual berdasarkan putusan nomor 39/PID.SUS/2019/PN Met?. Faktor penyebab timbulnya perbuatan pidana yaitu faktor ekonomi yang sering lebih dominan kurangnya kesejahteraan dan susahnya mendapat lowongan pekerjaan membuat orang menghalalkan segala cara untuk mendapatkan keuntungan, seseorang untuk melakukan suatu tindak pidana yang dilarang dan diancam dengan pidana, faktor kebiasaan merupakan suatu ciri khas dari seseorang yang suka berkehidupan berlebihan atau mewah, maka jalan pintas ia melakukan perbuatan tindak pidana dan faktor kesempatan adalah faktor yang juga dapat menghantarkan seseorang untuk melakukan perbuatan tindak pidana. Penerapan hukum oleh hakim terhadap pelaku tindak pidana turut serta dalam menawarkan layanan seksual berdasarkan Putusan Nomor 39/PID.SUS/2019/PN Met. Majelis Hakim mengatakan bahwa memperhatikan ketentuan Pasal 30 Jo Pasal 4 Ayat (2) UU RI No.44 Tahun 2008 tentang Pornografi Jo Pasal 55 Ayat (1) Ke-1 KUHP, Undang-undang Nomor 8 Tahun 1981 tentang hukum acara Pidana serta peraturan perundang-undangan lainnya yang bersangkutan, maka Majelis Hakim Pengadilan Negeri Kelas IB Kota Metro mengadilimenyatakan terdakwa telah terbukti secara sah dan meyakinkan bersalah melakukan tindak pidana turut serta dalam menawarkan layanan seksual dan menjatuhkan pidana terhadap Terdakwa I Hendi Bin M Lisin dan Terdakwa II Lala Rizky Septiani Binti Muzirzain dengan pidana penjara masing-masing selama 1 tahun dan pidana denda masing-masing sejumlah Rp.250.000.000,00 (dua ratus lima puluh juta rupiah). Saran Saran, berdasarkan daripada faktor penyebab para pelaku melakukan tindak pidana turut serta dalam menawarkan layanan seksual, Para Hakim dalam hal ini agar dapat memberikan sanksi pidana terhadap pelaku, putusan harus lebih berat karena perbuatan terdakwa merupakan bentuk dari kesalahan yang harus di dipertanggungjawabkan serta tidak ada alasan pembenar atau alasan yang menghapuskan pertanggungjawaban pidana bagi terdakwa. Hendaknya Hakim memberikan putusan pidana yang adil bagi terdakwa artinya hal tersebut dimaksudkan untuk memberikan dampak jera terhadap para pelaku tindak pidana, sehingga tidak dapat mengulangi terjadinya tindak pidana yang sama di kemudian hari. Pemerintah diharapkan dapat memberikan kemudahan akses pendidikan kepada masyarakat terkhusus untuk Kota Metro, menyediakan lapangan pekerjaan yang terverifikasi, sehingga agar dapat menekan bertumbuhnya tindak pidana turut serta dalam menawarkan layanan seksual. 
Kata Kunci : Penerapan Hukum. Pelaku Tindak Pidana, Turut Serta, Layanan Seksual.

\section{A. PENDAhuluan}

Perdagangan orang merupakan kejahatan yang luar biasa yang menggunakan berbagai modus operandi. Pada umumnya modus operandi yang dilakukan adalah pengiriman tenaga kerja, duta seni budaya, perkawinan pesanan, pemalsuan dokumen dan penyalahgunaan visa, pemindahan tenaga kerja prosedural yang dipindahkan secara illegal, jeratan hutang dan kerja paksa, adopsi anak atau penjualan orang. Pada beberapa tahun terakhir ini terjadi perubahan yang cukup signifikan pada modus operandi Tindak Pidana Perdagangan Orang. Sejumlah awak kapal menjadi korban perdagangan orang, serta munculnya modus baru yang menggunakan teknologi sebagai basis mekanisme kejahatan seperti prostitusi online ${ }^{1}$.

Penyebab utama terjadinya perdagangan orang adalah tingginya angka kemiskinan, selain itu yang menjadi pendorong terjadinya perdagangan orang adalah terbatasnya lapangan kerja, tingginya angka

\section{${ }^{1}$ Henny Nuraeny, Tindak pidana} perdagangan orang. Sinar Grafika, Jakarta. 2011. HIm. 110. pengangguran serta rendahnya tingkat pendidikan. Faktor lain yang juga menjadi penyebab adalah kurangnya pengetahuan dan informasi tentang cara-cara bekerja keluar negeri, gaya hidup yang konsumtif sehingga mereka rentan terhadap bujukan dan rayuan para calo tenaga kerja dan terjerat dalam perdagangan orang. Keinginan untuk hidup yang layak tapi dengan kemampuan yang kurang memadai dan kurang mengetahui informasi pasar menyebabkan perempuan dan anak terjebak dalam lilitan hutang ${ }^{2}$

Pemerintah Indonesia mempunyai sikap yang tegas untuk memerangi tindak perdagangan orang dengan menetapkan berbagai peraturan perudang-undangan antara lain UU No.21 Tahun 2007 Tentang Penghapusan Tindak Pidana Perdagangan Orang, UU No. 39 Tahun 2004 tentang Penempatan Perlindungan TKI keluar negeri, Kepres No.88 Tentang Rencana Aksi Nasional. Keseriusan pemerintah dalam memerangi Tindak Pidana Perdagangan Orang dengan menyelidiki, menindak dan

${ }^{2}$ Farhana, Aspek Hukum Perdagangan OrangDi Indonesia, Sinar Grafika, Jakarta. 2012. Hlm. 50 
menghukum pelaku, selain itu juga memberikan perlindungan dan bantuan kepada korban. ${ }^{3}$

Apabila berbicara mengenai penyertaan tindak pidana kata penyertaan dalam Kamus Besar Bahasa Indonesia berarti proses, cara, perbuatan menyertai atau menyertakan. Jelas bahwa makna dari istilah ini ialah bahwa ada dua orang atau lebih yang melakukan suatu tindak pidana atau dengan kata lain dua orang atau lebih mengambil bagian untuk mewujudkan suatu tindak pidana ${ }^{4}$. Sedangkan arti kata penyertaan menurut Wirjono Prodjodikoro adalah turut sertanya seorang atau lebih pada waktu seorang lain melakukan tindak pidana. Dalam proses penegakkan hukum pidana kerap dipergunakan Pasal 55 ayat (1) ke-1 KUHP yang lazim digunakan dalam penanganan suatu tindak pidana yang terjadi dan melibatkan lebih dari satu orang pelaku. Dalam kajian hukum pidana terkait pasal 55 KUHP secara teoritik dikenal dengan deelneming atau penyertaan. Dalam

${ }^{3}$ www.kemenppa.go.id/lib/uploads/list/158 $8 f$ kajian kebijakan tentang tindak pidana perdagangan orang. Diakses pada tanggal 8 agustus 2019, puku 03.03 WIB

${ }^{4}$ Kanter, Asas-Asas Hukum Pidana Di Indonnesia Dan Penerapannya. Storia Grafika, Jakarta. 2002, Hlm. 336 konteks ini deelneming merupakan suatu yang berkaitan peristiwa pidana yang pelakunya lebih dari satu orang, sehingga harus dicari peranan dan tanggung jawab masing-masing pelaku dari perbuatan pidana itu. ${ }^{5}$

Dari berbagai kasus perdagangan orang di Provinsi Lampung contoh nyata yaitu terdakwa Terdakwa I Hendi bin M.Lisin dan Terdakwa II lala Rizki Septani binti Muzirzain sebagai medepleger orang yang turut serta dalam tindak pidana perdagangan orang, terdakwa kasus perdagangan orang (trafficking), akhirnya terbukti secara sah dan menyakinkan bersalah melakukan tindak pidana "Turut Serta Menawarkan Layanan Seksual sebagaimana dalam dakwaan alternatif kedua Penuntut Umum divonis dengan Pidana Penjara masing-masing selama 1 (satu) Tahun dan Pidana Denda masing-masing sejumlah Rp250.000.000,00 (dua ratus lima puluh juta rupiah) dengan ketentuan apabila pidana denda tersebut tidak dibayar maka diganti dengan Pidana Kurungan masing-masing selama 1 (satu) bulan oleh majelis Hakim Pengadilan Negeri Metro.

\footnotetext{
${ }^{5}$ Wirjono Prodjodikoro, Asas-asas Hukum Pidana Di Indonesia, Cet. Ke-7.Bandung. 1989. Hlm. 108.
} 
Hendi bin M.Lisin dan lala Rizki Septani binti Muzirzain dinyatakan bersalah melakukan tindak pidana pornografi dengan pemberatan sebagaimana diatur dan diancam pidana dalam Pasal 30 Jo Pasal 4 Ayat (2) UU RI No.44 Tahun 2008 tentang Pornografi Jo Pasal 55 Ayat (1) Ke-1 KUHP, akhirnya divonis pidana penjara selama 1 Tahun dan 6 (enam bulan) dan denda sejumlah Rp250.000.000,00 (dua ratus lima puluh juta rupiah) subsidair 2 (dua) bulan kurungan dikurangi selama terdakwa berada dalam tahanan dengan perintah terdakwa tetap ditahan oleh majelis Hakim Pengadian Negeri Metro

\section{B. METODE PENELITIAN}

Metode penelitian menggunakan pendekatan yuridis normatif dan empiris. Jenis data yang digunakan adalah data sekunder dan data primer. Pengumpulan data melalui penelitian kepustakaan (library research) dan penelitian lapangan (field research). Analisis data yang digunakan adalah yuridis kualitatif.

\section{PEMBAHASAN}

1. FaktorPelaku Melakukan Tindak Pidana Turut Serta Dalam Menawarkan Layanan Seksual (Human Trafficking)
Berdasarkan Putusan Nomor : 39/PID.SUS/2019/PN Met.

Berdasarkan hasil wawancara selama penelitian pada Polres Metro Lampung, Ipda Lisma selaku Kanit PPA Polres Metro menjelaskan bahwa faktor penyebab timbulnya tindak pidana atau kejahatan secara umum akan memperlihatkan banyaknya variasi serta bermacam-macam aspek yang dapat mendukung sehingga terjadinya suatu kejahatan. Teori-teori tentang faktor penyebab terjadinya kejahatan sangat banyak dikemukakan oleh para sarjana, dimana pendapat yang satu dengan yang lainnya saling berbeda-beda, hal ini timbul karena tinjauan dengan latar belakang yang berbeda-beda pula. Namun kendati demikian diantara teori tersebut ada unsur-unsur yang secara prinsip menunjukkan persamaan sehingga jika digolongkan maka dari perbedaan dan persamaan tersebut dapat ditarik secara garis besar faktor-faktor yang sangan menentukan terhadap suatu kejahatan.

Selanjutnya Menurut Ipda Lisma selaku Kanit PPA Polres Metro mengatakan bahwa lingkungan sosial daerah tempat tinggal, kehidupan sosial dan ekonomi dengan mobilitas penduduk banyak mempengaruhi individu dalam membentuk prilaku 
kriminal, sebab pengaruh stabilitas seseorang tidak akan terlepas dari pengaruh lingkungannya. Apabila diperhatikan beberapa pendapat diatas tentang faktor-faktor penyebab timbulnya kejahatan maka sulit untuk menentukan faktor mana yang lebih dominan, hal ini sejalan dengan pemikiran bahwa memang faktorfaktor tersebut sebagai penyebab kejahatan tidak dominan berdiri sendiri tetapi satu dengan yang lainnya saling mempengaruhi.

Berdasarkan hasil penelitian di Lembaga Pemasyarakatan Kelas IIA Kota Metro yang pada pokoknya menyimpulkan bahwa perbuatan yang dilakukan oleh Terdakwa dilatarbelakangi oleh beberapa Faktor sebagai berikut :

\section{Faktor Ekonomi}

Pelaku bercerita salah satu faktor terlibatnya dirinya dalam menawarkan layanan seseorang yaitu faktor ekonomi. Rendahnya perekonomian yang dimilikinya dan sulitnya untuk mencari pekerjaan sampai para Terdakwa tergoda dengan pekerjaan yang mudah dan menghasilan uang yang cukup bayak. Hanya dengan cara mencarikan pengguna jasa wanita pekerja seks komersial (PSK) dan mengantar kepenginapan untuk dipertemukan kepada (pengguna jasa) wanita untuk melayani para tamu laki-laki yang akan menggunakan jasa para pekerja seks komersialselain itu juga di karenakan harus membiayai kebutuhan dan membayar hutang yang dimilikinya.

2. Faktor Lingkungan dan Pergaulan Bebas

Lingkungan menjadi salah satu faktor terjadinya tindak pidana turut serta dalam menawarkan layanan seksual. Di zaman sekarang ini lingkungan sangat menentukan kehidupan. Jika bergaul dilingkungan yang sehat tidak ada masalah. Sebaliknya jika bergaul dilingkungan yang tidak sehatlah yang bisa menjerumuskan kedalam dunia prostitusi. Seperti yang diungkapkan para Terdakwa yang kini status status hukumnya menjadi Terpidana di Lembaga Pemasyarakatan Kelas IIA Kota Metro mengatakan bahwa, di karenakan pergaulan mereka yang bebas, memiliki teman laki-laki yang banyak dan memiliki link yang luas sehingga ia di percayakan oleh teman yang ia perdangankan dan 
memintanyauntukmencarikan(peng guna jasa PSK)

Berdasarkan pada uraian diatas dapat diketahui bahwa faktor yang menyebabkan pelaku melakukan tindak pidana turut serta dalam menawarkan layanan seksual keadaan ekonomi dapat menjadi faktor yang cukup mendominasi perbuatan kejahatan, pengakuan yang diuangkapkan oleh para Terpidana faktor ekonomi adalah satu alasan mengapa mereka melakukan pekerjaan sebagai menawarkan layanan seksual. Dari pekerjaan tersebut dapat memenuhi kebutuhan mereka dengan mudah, hal ini di karenakan hasil dari pekerjaan tersebut cukup bayak dibanding dengan mereka yang harus bersusah payah bekerja keras. Selain itu juga pergaulan yang tak terkontrol membuat seseorang menjadi terjerumus dalam hal-hal yang negative, zaman dimana teknologi semakin canggih mendorong seseorang dengan mudah terjangkit pergaulan bebas. Budaya barat yang sekarang hampir mendominasi di kehidupan sehari-hari menjadiakan setiap orang zaman sekarang tidak lagi didominasi oleh pendidikan keluarga namun lebih banyak pendidikan dari lingkungan pergaulannya. Berdasarkan alasan tersebutlah sehingga mendorong seorang anak untuk melakukan tindakan kejahatan yang dapat merugikan orang lain.
Menurut Dwi Nanda Saputra selaku Kepala Seksi Pidana Umum mengatakan bahwa, faktor penyebab penyebab pelaku melakukan tindak pidana turut serta dalam menawarkan layanan seksual adalah disebabkan oleh beberapa faktor antara lain :

1. Faktor moral atau sikap batin yang jahat

Faktor ini disebabkan faktor ini disebabkan bahwa dalam diri pelaku terdapat gejala-gejala untuk melakukan tindak pidana dilihat dari pekerjaan pelaku, perilaku pelaku seseorang menunjukkan bahwa pelaku mengetahui perbuatannya merupakan tindak pidana dan atas perbuatannya dapat dikenakan sanksi pidana. pelaku sadar akan hukum yang dilanggarnya tetapi karena moral yang rendah atau sikap batin yang jahat di dalam diri pelaku (intern), menyebabkan pelaku melakukan tindak pidana turut serta dalam menawarkan layanan seksual, dimana Terdakwa I HENDI Bin M.LISIN dan terdakwa II LALA RIZKI SEPTIANI Binti MUNZIRZAIN pada hari Minggu tanggal 23 Desember 2018 sekira pukul 16.00 WIB atau setidaktidaknya pada suatu waktu dalam bulan Desember tahun 2018 atau setidaknya pada waktu-waktu tertentu 
masih dalam tahun 2018 bertempat di Jalan Jendral Sudirman Kelurahan Ganjar Asri Kecamatan Metro Barat Kota Metro tepatnya di Hotel Indah Permai Metro atau setidak-tidaknya pada suatu tempat dalam daerah hukum Pengadilan Negeri Metro yang berwenang memeriksa dan mengadili perkara ini, menyajikan secara ekslisit ketelanjangan atau tampilan yang mengesankan ketelanjangan, menyajikan secara eksplisit alat kelamain, mengekploitasi atau memamerkan aktivitas seksual atau menawarkan atau mengiklankan baik langsung maupun tidak langsung layanan seksual, orang yang melakukan, yang menyuruh melakukan, atau turut melakukan perbuatan itu Sebagaimana didakwakan dalam dakwaan alternatif yakni pasal 30 Jo pasal 4 ayat (2) UU RI No. 44 Tahun 2008 tentang Pornografi Jo Pasal 55 ayat (1) ke-1 KUHP.

Berdasarkan uraian tersebut di atas rendahnya moral atau sikap batin yang jahat dari diri pelaku disebabkan oleh hal-hal seperti kurangnya pengamanan agama dan norma dalam diri pelaku. Pendapat penulis ini berkaitan dengan teori faktor kejahatan yang menganggap bahwa kejahatan sangat berkaitan dengan moralitas pelaku tindak pidana turut serta dalam menawarkan layanan seksual.

\section{Faktor Ekonomi}

Faktor ekonomi kurangnya kesejahteraan dan susahnya mendapat lowongan pekerjaan membuat orang menghalalkan segala cara untuk mendapatkan keuntungan. Pelaku yang berkeinginan untuk berpola hidup mewah jadi tidak cukup hanya terpenuhi kebutuhan primer tetapi juga gaya hidup mewah agar dapat diterima dalam lingkungan teman sepermainan dan agar dapat dikatakan modern. Ada hal lain pula yaitu mudahnya pelaku mendapatkan banyak uang dari setiap transaksi yang ia lakukan kepada orang yang akan menggunakan jasa wanita yang ia perdagangkan. Daripada ia harus bekerja yang belum tentu uang yang ia dapat dari pekerjaan itu dapat memenuhi kebutuhannya sehari-hari

3. Faktor Lingkungan

Lingkungan yang didominasi oleh orang-orang yang kebiasaan hidupnya buruk (mengalami penyimpangan sosial), sangat mempengaruhi tingkah laku seseorang yang dicerminkan oleh kebiasaan hidupnya sehari-hari. Lingkungan yang mengalami dekadensi moral yaitu adanya 
penurunan standar kemoralan seseorang/masyarakat terhadap standar baku/nilai-nilai yang sudah berlaku di masyarakat. Dalam hal ini faktor lingkungan sebenarnya bukan hanya berkaitan dengan faktor ekonomi yang telah di sebutkan sebelumnya diatas, sehingga dalam hal ini faktor lingkungan pada tindak pidana turut serta dalam menawarkan layanan seksual sangat mempengaruhi terjadinya tindak pidana turut serta dalam menawarkan layanan seksual sebab pelaku berada dalam lingkungan dan kebiasaan yang pergaulan sosialnya rendah, rendahnya moral penduduk, dan sering kali di lingkungan tersebut norma-norma sosial sudah sering dilanggar dan tidak ditaati lagi.

\section{Faktor Kesempatan}

Suatu kejahatan dapat terjadi apabila ada faktor kesempatan walaupun pelaku sudah mempunyai niat tetapi bila tidak ada kesempatan suatu tindak pidana tidak akan terjadi. Faktor kesempatan seseorang pada tindak pidana turut serta dalam menawarkan layanan seksual sangat mempengaruhi, karena pelaku memiliki jaringan yang luas kepada para laki-laki yang sering menggunakan jasa para pekerja seks komersial, terlebih menurut Dwi
Nanda Saputra selaku Kepala Seksi Pidana Umum mengatakan bahwa dalam fakta di persidangan menurut salah seorang saksi, pelaku adalah seorang mucikari sekaligus seorang pekerja seks komersial sehingga pelaku dengan jaringan yang luas dapat melakukan tindak pidana turut serta dalam menawarkan layanan seksual

Berdasarkan pada uraian diatas dapat diketahui bahwa faktor yang menyebabkan pelaku melakukan tindak pidana turut serta dalam menawarkan layanan seksual karena terdesak masalah kebutuhan ekonomi untuk memenuhi kebutuhan hidupnya, selain itu pula faktor kesempatan lebih besar berpengaruh karena pelaku mempunyai jaringan yang luas kepada para laki-laki yang sering menggunakan jasa para pekerja seks komersial terlebih pelaku sendiri adalah seorang pekerja seks komersial sekaligus mucikari, yang besar kemungkinan melalui jaringan yang luas pelaku dapat dengan mudah melakukan perbuatan ikut serta dalam menawarkan layanan seksual.

Dari faktor-faktor yang telah diuraikan diatas, penulis berpendapat ada beberapa faktor penyebab timbulnya perbuatan pidana yaitu faktor ekonomi yang sering lebih dominan kurangnya kesejahteraan 
dan susahnya mendapat lowongan pekerjaan membuat orang menghalalkan segala cara untuk mendapatkan keuntungan, seseorang untuk melakukan suatu tindak pidana yang dilarang dan diancam dengan pidana, faktor kebiasaan merupakan suatu ciri khas dari seseorang yang suka berkehidupan berlebihan atau mewah, maka jalan pintas ia melakukan perbuatan tindak pidana dan faktor kesempatan adalah faktor yang juga dapat menghantarkan seseorang untuk melakukan perbuatan tindak pidana.

Berdasarkan dari teori tersebut, maka dapat dianalisis bahwa faktor penyebab pelaku melakukan tindak pidana turut serta dalam menawarkan layanan seksual disebabkan oleh beberapa faktor antara lain faktor moral atau sikap batin yang jahat, faktor ekonomi, faktor lingkungan dan faktor kesempatan.

\section{Penerapan Hukum Oleh Hakim Terhadap Pelaku Tindak Pidana Turut Serta Dalam Menawarkan Layanan Seksual (Human Trafficking) Berdasarkan Putusan Nomor 39/PID.SUS/2019/PN Met.}

Berdasarkan hasil wawancara selama penelitian pada Pengadilan Negeri Kelas IB Metro DenganBeni Arisandi selaku Hakim Pengadilan Negeri Kelas IB Metro mengatakanbahwa Kebebasan Hakim menjatuhkan putusan dalam proses Peradilan Pidana terdapat dalam pasal 3 ayat (1) dan (2) Undang-Undang Nomor
48 Tahun 2009 Tentang Kekuasaan Kehakiman yang menyatakan : ayat (1) : dalam menjalankan tugas dan fungsinya, Hakim dan Hakim Konstitusi wajib menjaga kemandirian peradilan. ayat (2) : Segala campur tangan dalam urusan peradilan oleh pihak lain di luar kekuasaan kehakiman dilarang kecuali dalam hal-hal sebagaimana dimaksud dalam UndangUndang Dasar Negara Republik Indonesia Tahun 1945. Isi pasal tersebut dipertegas lagi dalam pasal 5 ayat (1) UndangUndang Nomor 48 Tahun 2009 Tentang Kekuasaan Kehakiman yang menyatakan : “ Hakim dan hakim konstitusi wajib menggali, mengikuti dan memahami nilainilai hukum dan rasa keadilan yang hidup dalam masyarakat".

Proses atau tahapan penjatuhan putusan oleh Hakim, dalam perkara pidana, menurut Moeljatno mengatakan bahwa dilakukan dalam beberapa tahap, yaitu :

1. Tahap menganalisis perbuatan pidana pada saat Hakim menganalisis, Apakah terdakwa melakukan perbuatan pidana atau tidak, yang dipandang primer adalah segi masyarakat, yaitu perbuatan tersebut sebagai dalam rumusan suatu aturan pidana.

2. Tahap menganalisis tanggung jawab pidana Jika seorang terdakwa dinyatakan terbukti melakukan perbuatan pidana melanggar suatu pasal tertentu, Hakim menganalisis Apakah terdakwa dapat dinyatakan bertanggung jawab atas perbuatan pidana yang dilakukannya. 
3. tahap penentuan pemidanaan Hakim akan menjatuhkan pidana bila unsur-unsur telah terpenuhi dengan melihat pasal undangundang yang dilanggar oleh pelaku. dengan dijatuhkannya pidana, naeun pelaku sudah jelas sebagai terdakwa.

Menurut Moeljatno Mengatakan bahwa putusan hakim juga berpedoman pada tiga (3) hal yaitu :

1. Unsur yuridis, yang merupakan unsur pertama dan utama.

2. Unsur filosofis, berintikan kebenaran dan keadilan.

3. Unsur sosiologis, yaitu mempertimbangkan tata nilai budaya yang hidup dan berkembang dalam masyarakat.

Lebih lanjut Moeljatno mengatakan bahwa seorang Hakim dalam menjatuhkan putusan nya mempertimbangkan hal-hal sebagai berikut :

1. Faktor yuridis, yaitu undangundang dan teori-teori yang berkaitan dengan kasus atau perkara.

2. Faktor non yuridis, yaitu melihat dari lingkungan dan berdasarkan hati nurani dari hakim itu sendiri.

Berdasarkan teori diatas, Menurut Beni Arisandi selaku hakim di pengadilan negeri kelas IB Kota Metro dalam perkara tindak pidana turut serta dalam menawarkan layanan seksual Nomor 39/PID.SUS/2019/PN Met, didalam pertimbangan Hakim dalam menjatuhkan putusan terhadap tindak pidana turut serta dalam menawarkan layanan seksual mempertimbangkan berdasarkan faktafakta yang terungkap dalam persidangan dapat memilih langsung untuk membuktikan dan mempertimbangkan dakwaan alternatif kedua dimana Terdakwa didakwa dimana Terdakwa didakwa melanggar Pasal 30 Jo pasal 4 Ayat (2) UU RI No,44 Tahun 2008 Tentang Pornografi Jo Pasal 55 Ayat (1) Ke-1 KUHP. Majelis hakim mempertimbangkan sebagai berikut :

\section{a. Unsur Setiap Orang}

Menimbang, bahwa yang dimaksud dengan "barang siapa" dalam unsur ini adalah tertuju pada setiap subyek hukum yang dihadapkan oleh Jaksa/Penuntut Umum dengan suatu dakwaan ke depan persidangan serta dapat dipertanggungjawabkan atas suatu perbuatannya ;

Menimbang, bahwa dipersidangan telah dihadapkan Terdakwa I Hendi bin M.Lisin dan Terdakwa II Lala Rizki Septiani binti Muzir Zain sebagaimana tersebut di dalam dakwaan Penuntut Umum dan berdasarkan keterangan para saksi dalam perkara ini serta pengakuan terdakwa sendiri, dengan identitas seperti dalam dakwaan Penuntut Umum sebagaimana tersebut diatas dan bukan orang lain serta terdakwa juga dalam keadaan sehat jasmani maupun rohani dan mampu bertanggung jawab, sehingga dengan demikian unsur 
"setiap orang" telah terpenuhi dan

terbukti menurut hukum, dari pengertian tersebut bahwa unsur kesatu barang siapa telah terpenuhi.

b. Unsur menyajikan secara ekpslisit ketelanjangan atau tampilan yang mengesankan ketelanjangan, menyajikan secara eksplisit alat kelamin, mengeksploitasi atau memamerkan aktivitas seksual atau menawarkan atau mengiklankan baik langsung maupun tidak langsung layanan seksual, orang yang melakukan, yang menyuruh melakukan, atau turut melakukan perbuatan itu;

Menimbang, bahwa dalam melihat unsur kedua akan dipertimbangkan secara sinergitas dan merupakan bagian dari sub-sub unsur yang perlu dibuktikan secara materil pidana, sebagaimana pengertian seksual perlu dibuktikan secara melawan hukum bahwa perbuatan tersebut sebagaimana aturan dalam perkara a quo

Menimbang, bahwa dalam pengertian secara seksual adalah suatu hubungan layaknya suami istri yang bermakna ilegal, penyedia atau penawaran layanan tersebut secara aktif maupun pasif menawarkan kegiatan hubungan layaknya suami istri kepada pihak lain melalui berbagai media;

Menimbang, bahwa berdasarkan fakta-fakta hukum di persidangan menyebutkan bahwa terdakwa Lala dalam perkara ini terdakwa berperan sebagai perantara antara tamu dan perempuan yang akan melayani hubungan intim dengan tamu tersebut;

Bahwa peran terdakwa Hendi adalah sebagai penyedia perempuan yang akan menemani tamu berhubungan intim, sedangkan saksi Amanda Karina Handayani berperan sebagai perempuan yang akan menemani tamu berhubungan intim dan saksi Desi berperan menemani terdakwa Lala pada saat ke Hotel Indah Permai

Bahwa terdakwa Lala pada hari Minggu tanggal 23 Desember tahun 2018 sekira jam 11.46 WIB terdakwa mendapatkan chatting melalui media sosial WhatsApp, dalam cat tersebut 1 (satu) orang laki-laki yang bernama Gandhi N Cahya akan memesan perempuan untuk teman berhubungan intim, selanjutnya dalam chat tersebut 
terdakwa Lala, mengirimkan beberapa foto perempuan yang akan dipilih oleh saksi Ghandi untuk teman berhubungan intim, selanjutnya dalam chat tersebut saksi Ghandi memilih 1 (satu) orang perempuan yang bernama Amanda Karina Handayani sebagai teman kencan. lalu terdakwa Lala menentukan harga untuk sekali menemani tidur dengan saksi Ghandi Seharga Rp Rp500.000,-- (lima ratus ribu rupiah), Setelah deal dengan harga tersebut terdapat dalam menanyakan untuk tempat berhubungan intim saksi Ghandi dengan saksi Amanda, Lalu saksi Gandi memberitahukan terdakwa bahwa tempatnya di Hotel Indah Permai Kota Metro, Lalu setelah terdakwa sepakat dengan 1 orang pemesanan tersebut terdakwa Lala menghubungi terdakwa Hendi melalui via telepon "KAK MANDA READY GAK”, lalu terdakwa Hendi menjawab "IYA READY”, JAM BERAPA" lalu terdakwa Lala berkata "IYA UDAH KAK NANTI ADA TAMU BO (BOOKING ORDER) JAM 15.00 WIB DI HOTEL INDAH PERMAI", Kemudian sekitar jam 15.30 WIB terdakwa Lala dihubungi oleh saksi Ghandi bahwa kamar sudah siap di kamar nomor 106;

Bahwa terdakwa LALA pergi bersama saksi DESI menuju ke Hotel Indah Permai Kota Metro, Sesampainya di sana terdapat Lala langsung menuju ke kamar 106 Hotel Indah Permai;

Bahwa terdakwa Lala mengambil uang sejumlah Rp.600.000,- (enam ratus ribu rupiah) dari saksi Ghandi Setelah terdakwa menerima uang tersebut kemudian datang beberapa polisi yang mengamankan terdakwa dan kemudian berdakwah bersama saksi Amanda dan saksi Desi dibawa ke Polres Metro;

Bahwa terdakwa Lala uang sejumlah Rp.600.000,- (enam ratus ribu rupiah) Dari saksi Ghandi Adalah sebagai tarif sekali pemesanan (Booking Order) Dan apabila kamu sudah berhubungan intim uang tersebut dibagi 3 (tiga) dengan rincian taksi Amanda sebesar Rp.400.000,- (empat ratus ribu rupiah) Fee terdakwa Hendi sebesar Rp.100.000,- (seratus ribu rupiah) dan Fee terdakwa Lala sebesar Rp.100.000,- (seratus ribu rupiah); 
Bahwa terdakwa Lala berperan sebagai PERANTARA antara tamu dan perempuan yang akan melayani berhubungan intim dengan tamu tersebut;

Bahwa terdakwa Lala berkomunikasi dengan tamu yaitu dengan mengirim foto-foto perempuan yang akan dipilih oleh tamu, kemudian selanjutnya tamu memilih foto perempuan yang akan menjadi temen kencan, lalu tamu menentukan tempat selanjutnya terdakwa membawa perempuan tersebut ketempat yang sudah ditentukan dan biasanya terdakwa meminta perempuan-perempuan tersebut kepada terdakwa HENDI karena sebelumnya terdakwa adalah anak buah dari terdakwa HENDI;

Bahwa untuk pemesanan BO (Booking Order) untuk perempuan yang akan menemani tamu berhubungan intim, biasanya terdakwa mendapatkan pelanggan dan konsumen dari kawan terdakwa yang terdakwa kenal dan kemudian konsumen langsung berhubungan dengan terdakwa lala melalui aplikasi Whatsapp;
Bahwa terdakwa Lala juga pernah menyuruh terdakwa HENDI untuk menerima BO (Booking Order) untuk terdakwa sendiri;

Menimbang, bahwa berdasarkan fakta-fakta hukum yang dihubungkan dengan pengertian diatas maka Majelis Hakim berpendapat unsur menawarkan layanan seksual, orang yang melakukan, yang menyuruh melakukan, atau turut serta melakukan perbuatan itu telah terpenuh;

Menimbang, bahwa Majelis Hakim sependapat dengan Penuntut Umum yang menyatakan secara kolektif, maka jelas kapasitas dan tanggung jawab atas perbuatan yang manayang harus dipertanggungjawabkan seorang pelaku tindak pidana (Terdakwa) apakah dalam posisinya sebagai yang melakukan. Meskipun disisi lain terhadap soal ini ada pendapat yang berbeda, tetapi tentu jika dikaitkan dengan Pasal 55 KUHP adanya kerjasama secara kolektif adalah baru langkah permulaan bagi menentukan peran dan tanggungjawab pelaku tindak pidana oleh karenanya dijadikan sebagai dasar untuk menjatuhkan 
pidana tanpa ada (disparitas) baik itu pelaku atau turut serta dan mengingat didalam Pasal 30 dijelaskan yaitu Setiap orang yang menyediakan jasa pornografi;

Menimbang, bahwa oleh karena semua unsur-unsur dalam dakwaan alternatif kedua telah terpenuhi, maka oleh karena itu Terdakwa tersebut haruslah dinyatakan bersalah dan dijatuhi pidana yang setimpal dengan perbuatannya;

Menurut Benny Arisandiselaku Majelis Hakim Mengatakan bahwa berdasarkan unsur-unsur diatas, Majelis Hakim dalam persidangan tidak menemukan adanya alasan pemaaf maupun pembenar pada diri terdakwa, yang dapat menghapuskan sifat perbuatan melawan hukum perbuatan Terdakwa, karenanya Terdakwa haruslah bertanggung jawab atas perbuatannya yang terbukti tersebut diatas;

Selanjutnya menurut Benny Arisandimengatakan bahwa untuk menjatuhkan pidana terhadap Terdakwa, maka perlu dipertimbangkan terlebih dahulu keadaan yang memberatkan dan yang meringankan Terdakwa, diantaranya;

1. Keadaan yang memberatkan :

a. Perbuatan para Terdakwa meresahkan masyarakat;

b. Perbuatan para Terdakwa menimbulkan image negatif ditengah masyarakat

c. Perbuatan para Terdakwa dapat menimbulkan penyakit masyarakat dalam pornografi dan pornoaksi

2. Keadaan yang meringankan:

a. Para Terdakwa bersikap sopan di persidangan

b. Para Terdakwa menyesali perbuatannya dan berjanji tidak akan melakukan lagi perbuatan yang dapat dihukum;

c. Para Terdakwa memiliki tanggungan keluarga;

Selanjutnya menurut Benny Arisandi selaku Majelis Hakim juga mengatakan bahwa memperhatikan ketentuan Pasal 30 Jo Pasal 4 Ayat (2) UU RI No.44 Tahun 2008 tentang Pornografi Jo Pasal 55 Ayat (1) Ke-1 KUHP, Undang-undang Nomor 8 Tahun 
1981 tentang hukum acara Pidana serta peraturan perundangundangan lainnya yang bersangkutan, maka Majelis Hakim Pengadilan Negeri Kelas IB Kota Metro mengadili sebagai berikut :

1. Menyatakan TerdakwaI Hendibin M. Lisin dan Terdakwa II Lala Rizky Setiani Binti Muzirzain terbukti secara sah dan meyakinkan bersalah melakukan tindak pidana Turut serta dalam menawarkan layanan seksual sebagaimana dalam dakwaan alternatif kedua penuntut umum

2. Menjatuhkan pidana terhadap Terdakwa I Hendi Bin $M$ Lisin dan Terdakwa II Lala Rizky Septiani Binti Muzirzain dengan pidana penjara masing-masing selama 1 tahun dan pidana denda masingmasing sejumlah Rp.250.000.000,00 (dua ratus lima puluh juta rupiah) Dengan ketentuan apabila pidana denda tersebut tidak dibayar maka akan diganti dengan Pidana kurungan masing-masing selama 1 (satu) bulan

3. Menetapkan masa penangkapan dan penahanan yang telah dijalani para terdakwa masingmasing dikurangi seluruhnya dari pidana yang dijatuhkan

4. Menetapkan para terdakwa tetap ditahan

5. Menyatakan barang bukti berupa

- 1 (satu) Unit HP merk OPPO F1S Tipe A1601, warna rose gold dengan nomor IMEI $1: 863525032952014$, IMEI 2:863525032952006;
- 1 (satu) Unit HP merk NOKIA 225 Tipe RM-1011, warna putih dengan nomor IMEI $1: 353670 / 06 / 058753 / 5, \quad$ IMEI 2:353670/06/058753/5;

- 1 (satu) buah HP merk OPPO Tipe A3S warna merah dengan nimor

IMEI $1: 862326044642870, \quad$ IMEI 2:8623260446286;

Dirampas Untuk Negara;

- 1 (satu) buah Nota Sewa Kamar Hotel Indah Permai;

Untuk Dimusnahkan;

- Uang Tunai sebesar Rp.600.000,- (enam ratus ribu rupiah);

Dikembalikan kepada Saksi Soeghandi N Cahya bin Nurdi Yasin;

6. Membebankan para Terdakwa untuk membayar biaya perkara masing-masing sejumlah Rp2.00,00 (dua ribu rupiah);

3. Upaya Menanggulangi Pelaku Tindak Pidana Turut Serta Dalam Menawarkan Layanan Seksual

Polri melaksanakan tugasnya dengan konsep dan pola pembinaan dalam wujud pemberian pengayoman, perlindungan dan pelayanan kepada masyarakat, agar masyarakat merasa aman, tertib dan tentram dalam menjalankan aktifitasnya sehari-hari. Sedangkan tindakan represif yang dilakukan Polri dapat berupa dengan mengadakan penyidikan atas kejahatan dan pelanggaran menurut ketentuan dalam undang-undang. Tentunya tindakan represif ini 
merupakan tugas kepolisian dalam bidang peradilan atau penegakan hukum sebagaimana menjadi tugas serta amanat dari peraturan yang berlaku.

Berdasarkan hasil wawancara Ipda Lisma selaku Kanit PPA Polres Metro berkaitan dengan penegakan hukum, peranan yang ideal dan peranan yang sebenarnya adalah memang peranan yang di kehendaki dan diharapkan oleh hukum di tetapkan oleh undangundang. Sedangkan peran yang di anggap diri sendiri dan peran yang sebenarnya telah dilakukan adalah peran yang mempertimbangakan antara kehendak hukum yang tertulis dengan kenyataankenyataan, dalam hal ini kehendak hukum harus mementukan dengan kenyataan yang ada.

Pendekatan yang digunakan dalam rangka upaya melakukan penanggulangan kejahatan melalui sarana pendekatan kriminal dapat menggunakan sarana penal dan non penal. Kebijakan dengan sarana penal adalah upaya penanggulangan kejahatan dengan menggunakan sarana pidana. Dalam hal ini telah terjadi semacam perumusan pidana dan pemidanaan yang telah dilegalkan melalui perundnag-undangan. Sehingga, telah ada kepastian hukum dalam melakukan penanggulangan maupun pemecahan terhadap pelanggaran atau kejahatan yang dilakukan oleh para pelaku kajahatan. Kebijakan kriminal dengan sarana penal ini bersifat represif. Maka dari itu, fungsionalisasi hukum pidana sangatlah terlihat dalam pelaksanaan kebijakan kriminal ini. Kebijakan kriminal dengan sarana non penal artinya upaya penanggulangan kejahatan dengan tidak melakukan hukum pidana.

Upaya non penal dapat juga diartikan sebagai upaya yang bersifat preventif, misalnya memperbaiki kondisi-kondisi tertentu dalam masyarakat atau melakukan pengwasan tertentu sebagai upaya prevensi terhadap kejahatan. Selain itu, dapat juga berbentuk sosialisasi terhadap suatu perundang-undangan yang baru, yang didalamnya mencangkup suatu kriminalisasi perbuatan tertentu yang menjadi gejala sosial dalam masyarakat modern. ${ }^{6}$

Dalam hal ini ada beberapa upaya yang dilakukan oleh Polda Lampung khususnya dalam wilayah hukum Polres Kota Metro yaitu :

\section{Upaya Preventif}

Upaya preventif yaitu, segala usaha dan kegiatan dibidang kepolisian untuk menjaga keamanan dan ketertiban masyarakat, memelihara

\footnotetext{
${ }^{6}$ Soerjono Soekanto. Faktor-faktor yang Mempengaruhi Penegakan Hukum. Rajawali Pers Cetakan ke-10, Jakarta. 1983. Hlm. 73
} 
keselamatan orang-orang dan harta bendanya termasuk member perlindungan dan pertolongan, khususnya mencegah dilakukannya perbuatan-perbuatan lain yang hakekatnya dapat mengancam atau membahayakan ketertiban dan ketentraman umum. Pihak kepolisian dalam hal melakukan upaya pencegahan yang bersifat preventif yag berhubungan dengan prostitusi online, maka pihak Polres Metro bekerjasama dengan Dinas PPA setempat memberikan penyuluhanpenyuluhan dan sosialisasi kepada masyarakat mengenai dampak negative apabila memilih pekerjaan sebagai pekerja seks komersial maupun menawarkan layanan seksual dan memberikan penyuluhan mengenai tindak pidana yang akan dikenakan kepada masyarakat apabila masyarakat tersebut memilih untuk mejadi mucikari, germo atau pekerja seks komersial, penyuluhan dan soaialisasi kepada masyarakat ini dilakukan untuk menghindari betambahnya kasus tersebut yang sudah ada didalam masyarakat.

Upaya lain yang dilakukan oleh pihak Polres Metro ialah mencari informasi secara terus menerus melalui media internet dengan tujuan agar Kepolisian Polres metro dapat menangkap dan mengurangi para mucikari lainnya yang masih bisa sampai sekarang melakukan transaksi prostitusi melalui layanan internet dengan pengguna jasa (pria hidung belang) yang ingin memakai pekerja seks komersial tersebut, polisi juga berharap dapat membongkar jaringan prostitusi melalui media online tersebut agar masyarakat dapat hidup lebih aman, nyaman, dan tertib.

\section{Upaya Represif}

Upaya represif yaitu upaya yang dilakukan setelah perbuatan yang bersifat pelanggaran atau kejahatan terjadi. Kepolisian mengadakan penyelesaian dalam bentuk memeriksa 
seorang atau orang-orang yang disangka melakukan perbuatan itu. Setelah penyelesaian pemeriksaan oleh kepolisian sudah dianggap selesai maka akan diserahkan kepada kejaksaan pihak Polres Metro dalam hal melakukan upaya yang bersifat represif yang berhubungan dengan turut serta dalam menawarkan layanan seksual, maka Polres Metro melakukan penagkapan terhadap para pelaku dan para pengguna jasa pekerja seks komersial tersebut untuk diberikan hukuman yang sesuai dengan Undang-Undang yang belaku saat ini

Dengan demikian berdasarkan dari uraian diatas maka dapat dianalisis bahwa diperlukan komitmen dalam penegakan hukum terhadap kejahatan prostitusi online sebagai tindak pidana dan diperlukan peningkatan kualitas sumber daya penegak hukum baik dalam penguasaan terhadap hukum, penggunaan bahasa asing dan bahasa hukum maupun penguasaan terhadap sarana dan fasilitas dalam penegakan hukum. Diperlukan sinergi antara kesadaran hukum dan kesadaran moral dari masyarakat dalam penegakan hukum terhadap tindak pidana turut serta dalam menawarkan layanan seksual sehingga para pengguna internet selalu berpegang pada hukum, cyber ethics, nilai-nilai, moral dan agama yang mereka anut.

\section{PENUTUP}

Berdasarkan hasil dari pembahasan dan penelitian terhadap permasalahan maka dapat disimpulkan sebagai berikut :

1. Faktor penyebab pelaku melakukan tindak pidana turut serta dalam menawarkan layanan seksual disebabkan beberapa faktor antara lain Faktor Ekonomi, Faktor Lingkungan,Faktor Pergaulan Bebas, Faktor Moral atau Sikap Batin Yang Jahat, danFaktor Kesempatan

2. Penerapan Hukum oleh Hakim terhadap Pelaku Tindak Pidana Turut Serta Dalam Menawarkan Layanan Seksual Berdasarkan Perkara No 39/PID.SUS/2019/PN Met. Majelis Hakim menyatakan telah terbukti secara sah dan meyakinkan bersalah melakukan 
tindak pidana turut serta dalam menawarkan layanan seksual dan menjatuhkan pidana terhadap Terdakwa I Hendi Bin M Lisin dan Terdakwa II Lala Rizky Septiani Binti Muzirzain dengan pidana penjara masing-masing selama 1 tahun dan pidana denda masingmasing sejumlah Rp.250.000.000,00 (dua ratus lima puluh juta rupiah) Dengan ketentuan apabila pidana denda tersebut tidak dibayar maka akan diganti dengan Pidana kurungan masing-masing selama 1 (satu) bulan.

3. Upaya Menanggulangi Pelaku Tindak Pidana Turut Serta Dalam Menawarkan Layanan Seksual. Ada beberapa upaya yang dilakukan oleh Polda Lampung khususnya dalam wilayah hukum Polres Kota Metro yaitu Upaya penal berupa tindakan represif yaitu upaya yang dilakukan setelah perbuatan yang bersifat pelanggaran atau kejahatan terjadi. Kepolisian mengadakan penyelesaian dalam bentuk memeriksa seorang atau orangorang yang disangka melakukan perbuatan itu untuk diberikan hukuman yang sesuai dengan Undang-Undang yang belaku saat ini. Upaya Non Penal Pihak kepolisian dalam hal melakukan upaya pencegahan yang bersifat preventif yag berhubungan dengan prostitusi online, maka pihak Polres Metro bekerjasama dengan Dinas PPA setempat memberikan penyuluhan-penyuluhan dan sosialisasi kepada masyarakat

Berdasarkan kesimpulan di atas, dapat diberikan saran antara lain sebagai berikut:

1. Berdasarkan daripada faktor penyebab para pelaku melakukan tindak pidana turut serta dalam menawarkan layanan seksual, Para Hakim dalam hal ini agar dapat memberikan sanksi pidana terhadap tindak pidana turut serta dalam menawarkan layanan seksual putusan harus lebih berat karena perbuatan terdakwa merupakan bentuk dari kesalahan yang harus di dipertanggungjawabkan, tidak ada alasan pembenar atau alasan yang menghapuskan

pertanggungjawaban pidana bagi terdakwa.

2. Hendaknya kepada Hakim memberikan putusan pidana yang adil bagi terdakwa artinya hal tersebut dimaksudkan untuk 
memberikan dampak jera terhadap para pelaku tindak pidana, sehingga tidak dapat mengulangi terjadinya tindak pidana yang sama di kemudian hari dan diharapkan kepada aparat penegak hukum khususnya Hakim dalam memberikan sanksi kepada para terdakwa, Hakim dapat menggali nilai-nilai hukum yang terdapat dalam masyarakat tersebut. Hal ini diperuntukkan untuk menciptakan rasa keadilan terhadap masyarakat.

3. Diperlukan komitmen dalam penegakan hukum terhadap kejahatan turut serta dalam menawarkan layanan seksual sebagai tindak pidana dan diperlukan peningkatan kualitas sumber daya penegak hukum serta sinergi antara kesadaran hukum dan kesadaran moral dari masyarakat dalam penegakan hukum terhadap tindak pidana dalam menawarkan layanan seksual. Diharapkan kepada Polda Lampung dalam hal ini Polres Metro untuk dapat mengambil peran yang lebih besar dalam penanggulangan dan pencegahan tindak pidana turut serta dalam menawarkan layanan seksual. Dan juga Pemerintah diharapkan dapat memberikan kemudahan akses pendidikan kepada masyarakat terkhusus untuk Kota Metro, menyediakan lapangan pekerjaan yang terverifikasi, sehingga agar dapat menekan bertumbuhnya tindak pidana turut serta dalam menawarkan layanan seksual.

\section{DAFTAR PUSTAKA}

Henny Nuraeny, Tindak pidana perdagangan orang. Sinar Grafika, Jakarta. 2011.

Farhana, Aspek Hukum Perdagangan OrangDi Indonesia, Sinar Grafika, Jakarta. 2012.

www.kemenppa.go.id/lib/uploads/list/l $588 f$ kajian kebijakan tentang tindak pidana perdagangan orang. Diakses pada tanggal 8 agustus 2019, puku 03.03 WIB

Kanter, Asas-Asas Hukum Pidana Di Indonnesia Dan Penerapannya. Storia Grafika, Jakarta. 2002,

Wirjono Prodjodikoro, Asas-asas Hukum Pidana Di Indonesia, Cet. Ke7.Bandung. 1989.

Soerjono Soekanto. Faktor-faktor yang Mempengaruhi Penegakan Hukum. Rajawali Pers Cetakan ke-10, Jakarta. 1983. 
